\title{
Hydrophilic Polyester Microspheres: Effect of Molecular Weight and Copolymer Composition on Release of BSA
}

\author{
Amir H. Ghassemi • Mies J. van Steenbergen • Herre Talsma • Cornelus F. van Nostrum • Daan J. A. Crommelin • Wim E. Hennink
}

Received: 31 May 2010 / Accepted: 23 June 2010 / Published online: 3 July 2010

(C) The Author(s) 2010. This article is published with open access at Springerlink.com

\begin{abstract}
Purpose To study the release of a model protein, bovine serum albumin (BSA), from microspheres of an hydroxylated aliphatic polyester, poly(lactic-co-hydroxymethyl glycolic acid) (PLHMGA).

Methods BSA-loaded microspheres were prepared by a double emulsion solvent evaporation method. The effect of copolymer composition and the molecular weight of the copolymer on in vitro release and degradation were studied. The integrity of the released BSA was studied by fluorescence spectroscopy and size exclusion chromatography (SEC).

Results Microspheres prepared from PLHMGA with 50\% hydroxymethyl glycolic acid (HMG) showed a burst release followed by a sustained release in 5-10 days. PLHMGA microspheres prepared from a copolymer with 35\% and 25\% HMG showed a sustained release of BSA up to $80 \%$ for 30 and 60 days, respectively. The release of BSA was hardly affected by the molecular weight of the polymer. Fluorescence spectroscopy and SEC showed that the released BSA preserved its structural integrity. Microspheres were fully degradable, and the degradation time increased from $\sim 20$ days to 60 days when the HMG content decreased from $50 \%$ to $25 \%$.
\end{abstract}

Conclusions Taking the degradation and release data together, it can be concluded that the release of BSA from PLHMGA microspheres is governed by degradation of the microspheres.

A. H. Ghassemi • M. J. van Steenbergen • H. Talsma

C. F. van Nostrum • D. J. A. Crommelin • W. E. Hennink ( $\bowtie)$

Department of Pharmaceutics, Utrecht Institute

for Pharmaceutical Sciences (UIPS), Utrecht University

P.O. Box 80082, Sorbonnelaan 16

3508 TB Utrecht, The Netherlands

e-mail:w.e.hennink@uu.nl
KEY WORDS hydroxylated aliphatic polyester. microspheres · PLGA · protein stability · release

\section{INTRODUCTION}

Poly(lactic-co-glycolic acid) (PLGA) has been extensively investigated for the delivery of hormones, antigens, antibodies and enzymes (1,2). Lactic acid/glycolic acid copolymers degrade via hydrolysis of the ester bounds connecting the monomer units, and the degradation products are lactic and glycolic acid, which can be metabolized and/or excreted by the kidneys (3). However, due to the instability of proteins during preparation, storage and release, PLGA systems have drawbacks for protein delivery. One major concern of PLGA microspheres for the controlled release of proteins is the acidic $\mathrm{pH}$ that is generated in the degrading polymer matrix (4-7), which leads to denaturation and aggregation of encapsulated proteins and results in incomplete release (8). Furthermore, PLGA is rather hydrophobic, and proteins might adsorb onto surfaces of this polymer, which can be associated with protein unfolding and aggregation (9-11). Finally, it has been reported that acylation and deamidation of proteins might occur in degrading PLGA matrices (12-16). In our previous study (17), we investigated the suitability of microspheres of a hydrophilic polyester, poly(L-lactic-co-hydroxymethyl glycolic acid) (PLHMGA), based on L-lactide and glycolide with pendant hydroxyl groups for the release of macromolecular compounds (18). We showed that the release of a water-soluble polysaccharide (dextran blue) and a model protein (lysozyme) was governed by degradation of the microspheres. However, the release of lysozyme, depending on the copolymer concentration used for microspheres formulation, varied from $50 \%$ to $70 \%$ of the loaded 
amount, and some insoluble residues composed of aggregated protein and insoluble crystalline L-lactic acid oligomers remained after 30 days. In order to circumvent the formation of these crystalline oligomers during degradation and to obtain complete degradation of the microspheres, in the present study, we used D,L-lactide instead of L-lactide for synthesis of copolymers with HMG. Microspheres were prepared using a double emulsion solvent evaporation method. The degradation of the microspheres made from copolymers of D,Llactide and HMG with different copolymer composition and molecular weight was studied. The release of a model protein, bovine serum albumin (BSA), from PLHMGA microspheres was investigated. Furthermore, the structural integrity of the released protein was studied.

\section{MATERIALS AND METHODS}

\section{Materials}

O-Benzyl-L-serine was purchased from Senn Chemicals AG (Dielsdorf, Switzerland). Bovine serum albumin (BSA) was obtained from Sigma Chemical Company (St Louis, USA). D,L-lactide was obtained from Purac, The Netherlands. $\mathcal{N}, \mathcal{N}^{\prime}$-Dimethylformamide and methyl-tert-butyl ether (MTBE), peptide grade dichloromethane (DCM), methanol, chloroform and tetrahydrofurane (THF) were purchased from Biosolve (Valkenswaard, The Netherlands). Benzyl alcohol was obtained from Merck (Darmstadt, Germany). Toluene (Acros, Geel, Belgium) was distilled from $\mathrm{P}_{2} \mathrm{O}_{5}$ and stored over $3 \AA$ molecular sieves under argon. $\mathcal{N}, \mathcal{N}^{\prime}$-Dimethylaminopyridine (DMAP) and sodium azide $\left(\mathrm{NaN}_{3}, 99 \%\right.$ ) were obtained from Fluka (Zwijndrecht, The Netherlands). Disodium hydrogen phosphate dihydrate $\left(\mathrm{Na}_{2} \mathrm{HPO}_{4} \cdot 2 \mathrm{H}_{2} \mathrm{O}\right)$ and sodium dihydrogen phosphate monohydrate $\left(\mathrm{NaH}_{2} \mathrm{PO}_{4} \cdot \mathrm{H}_{2} \mathrm{O}\right)$ were purchased from Merck (Darmstadt, Germany). Polyvinyl alcohol (PVA; Mw 30,000-70,000; 88\% hydrolyzed) and tin (II) 2-ethylhexanoate $\left(\mathrm{SnOct}_{2}\right)$ were from Sigma-Aldrich, Inc., USA. BCA reagent was from Interchim, USA. Pd/C (Palladium, 10 wt \% on activated carbon, Degussa type E101 NE/W) was purchased from Aldrich, Zwijndrecht,
The Netherlands. Unless otherwise stated, all chemicals were used as received.

\section{Synthesis of Copolymers of 3S-(benzyloxymethyl)-6S- methyl-I, 4-dioxane-2, 5-dione with D, L-lactide}

3S-(benzyloxymethyl)-6S-methyl-1, 4-dioxane-2, 5-dione (BMMG) was synthesized according to Leemhuis et al. (18). The synthesized monomer BMMG was copolymerized with D,L-lactide at different monomer molar ratios (25/75, $35 / 65$ and $50 / 50 \% \mathrm{~mol} / \mathrm{mol}$ ) by melt copolymerization (Fig. 1) (18).

Briefly, for the synthesis of the 25/75 copolymer, BMMG (726 mg, $2.87 \mathrm{mmol}$ ) and D,L-lactide (1253 mg, $8.66 \mathrm{mmol}$ ) were transferred into a dried Schlenk tube under a dry nitrogen atmosphere. Benzyl alcohol (12.54 mg; $37 \mu \mathrm{l}$ from a $352 \mathrm{mg} / \mathrm{ml}$ toluene stock solution) and $\mathrm{SnOct}_{2}(23.5 \mathrm{mg} ; 71 \mu \mathrm{l}$ from $330 \mathrm{mg} / \mathrm{ml}$ toluene stock solution) were added. After evaporation of toluene under vacuum, the tube was sealed and immersed into a $130^{\circ} \mathrm{C}$ oil bath for $16 \mathrm{~h}$ while stirring. After cooling to room temperature, the obtained copolymer, poly(D, L-lactic acidran-benzyloxymethyl glycolic acid) (PLBMGA), was dissolved in chloroform and subsequently precipitated in cold methanol. After filtration, the polymer was vacuum dried to yield a $1.86 \mathrm{~g}$ white solid material, which was dissolved in $300 \mathrm{ml}$ distilled THF, followed by the addition of $10 \% \mathrm{w} / \mathrm{w} \mathrm{Pd} / \mathrm{C}$ catalyst to remove the benzyl protecting groups. The solution was stirred under hydrogen atmosphere for $16 \mathrm{~h}$, and then the catalyst was removed by Hyflo filter. Evaporation of THF yielded $1.5 \mathrm{~g}$ of poly(D,L-lacitde-co-hydroxymethyl glycolide) (PLHMGA). Copolymers of 35/65 and 50/50 BMMG and D,L-lactide were synthesized using the same method by adjusting the amounts of BMMG and D,L-lactide. Two copolymers of BMMG and D,L-lactide (35/65) with different molecular weights were synthesized at monomers to initiator (M/I) of 100 and 10.

\section{Polymer Characterization}

${ }^{1} \mathrm{H}$ NMR analysis of PLBMGA and PLHMGA was performed using a Gemini-300 $\mathrm{MHz}$ spectrometer at 298 K. Samples were dissolved in $\mathrm{CDCl}_{3}$.

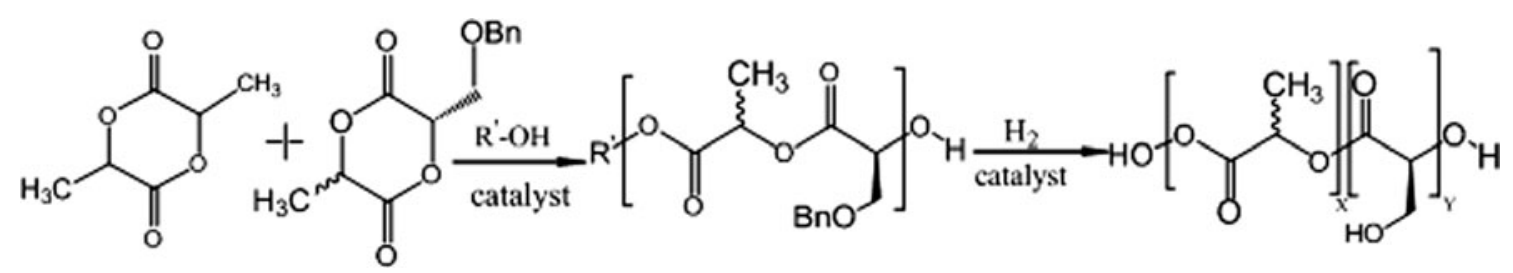

Fig. I Synthesis of hydrophilic aliphatic polyesters based on lactic acid and glycolic acid with pendant hydroxyl groups, poly(lactic-co-hydroxymethyl glycolic acid). 
The molecular weights of the obtained polymers were determined using GPC (Waters Alliance system), with a Waters 2695 separating module and a Waters 2414 refractive index detector. Two PL-gel $5 \mu \mathrm{m}$ Mixed-D columns fitted with a guard column (Polymer Labs, $M_{w}$ range $0.2-400 \mathrm{kDa}$ ) were used, and calibration was done using polystyrene standards with narrow molecularweight distributions. THF was used as the mobile phase (1 $\mathrm{ml} / \mathrm{min})(17)$.

The thermal properties of the protected (PLBMGA) and deprotected copolymers (PLHMGA) were measured using differential scanning calorimetry (TA instrument, Q2000). Approximately $5 \mathrm{mg}$ of either PLBMGA or PLHMGA was loaded into aluminum pans, and after heating from room temperature to $120^{\circ} \mathrm{C}$, with a heating rate of $5^{\circ} \mathrm{C} / \mathrm{min}$, samples were cooled down to $-50^{\circ} \mathrm{C}$. Thereafter, they were heated to $120^{\circ} \mathrm{C}$ with temperature modulation at $\pm 1^{\circ} \mathrm{C}$ and a ramping rate of $1^{\circ} \mathrm{C} / \mathrm{min}$. The second cycle was used to determine the glass transition temperature $\left(\mathrm{T}_{\mathrm{g}}\right)$ of synthesized polymers.

\section{Preparation of Microspheres}

BSA-loaded microspheres were prepared using a solvent evaporation technique $(17,19,20)$. Briefly, $125 \mu \mathrm{l}$ of a BSA solution in water $(50 \mathrm{mg} / \mathrm{ml})$ was emulsified with $500 \mu \mathrm{l}$ of a solution of $20 \%(\mathrm{w} / \mathrm{w})$ PLHMGA solution in DCM by using an IKA homogenizer (IKA Labortechnik Staufen, Germany) for $30 \mathrm{~s}$ at the highest speed to get an w/o primary emulsion. An emulsion stabilizer (500 $\mu \mathrm{l}$ 1\% PVA solution) was then added, and the mixture was vortexed for $30 \mathrm{~s}$ at maximum speed. The formed emulsion was subsequently transferred into a $5 \mathrm{ml} 0.5 \%$ PVA aqueous solution and stirred for $1 \mathrm{~h}$ at room temperature to evaporate DCM. Microspheres were collected by centrifugation (Laboratory centrifuge, 4 K 15 Germany) at $3000 \mathrm{~g}$ for $3 \mathrm{~min}$ and washed 3 times with $100 \mathrm{ml}$ reversed osmosis (RO) water and freeze dried overnight. The dried microspheres were stored at $-25^{\circ} \mathrm{C}$.

\section{Microspheres Characterization}

The microspheres' size distributions were analyzed by an Accusizer $^{\text {th }} 780$ (Optical particle sizer, Santa Barbara, California, USA). Results are reported as volumetric mean diameter.

The morphology of microspheres was analyzed using a Phenom ${ }^{\text {TM }}$ SEM (FEI Company, The Netherlands). The samples were mounted onto $12 \mathrm{~mm}$ diameter aluminum specimen stubs (Agar Scientific Ltd., England) using double-sided adhesive tape. The samples were sputter coated with a platinum coating prior to analysis.

\section{Protein Loading of the Microspheres}

Protein loading of the microspheres was determined by dissolving about $10 \mathrm{mg}$ of freeze-dried microspheres in $1 \mathrm{ml}$ DMSO. After $1 \mathrm{~h}$ incubation at room temperature, $5 \mathrm{ml}$ of a $0.05 \mathrm{M} \mathrm{NaOH}$ solution containing $0.5 \%$ (w/v) SDS (sodium dodecyl sulfate) was added, essentially as described by Hongkee et al. (21). The resulting solution was then analyzed for the total protein content by a BCA-microplate assay. BSA loading efficiency (LE) is reported as the amount of protein entrapped in the microspheres divided by the amount of protein added during the preparation of microspheres times $100 \%$. Loading capacity $(\mathrm{LC})$ is expressed as encapsulated amount of BSA divided by the total dry weight of the microspheres.

\section{In Vitro Release Studies}

BSA-loaded microspheres (20 mg) were suspended in a $1.5 \mathrm{ml}$ PBS (pH 7.4, $0.033 \mathrm{M} \mathrm{NaH}{ }_{2} \mathrm{PO}_{4}, 0.066 \mathrm{M}$ $\mathrm{Na}_{2} \mathrm{HPO}_{4}, 0.056 \mathrm{M} \mathrm{NaCl}$ and $0.05 \%$ (w/w) $\mathrm{NaN}_{3}$ ) and incubated at $37^{\circ} \mathrm{C}$ under mild agitation. Samples were collected at different time points after centrifugation of the microspheres' dispersion, followed by removing $1 \mathrm{ml}$ of the supernatant and replacing it with $1 \mathrm{ml}$ of fresh buffer. The samples were analyzed for their protein concentration by UPLC (Acquity UPLC®) equipped with a $\mathrm{BEH}$ $300 \mathrm{C} 181.7 \mu \mathrm{m}$ column. A gradient elution method was used with mobile phase A $\left(95 \% \quad \mathrm{H}_{2} \mathrm{O}, 5 \%\right.$ ACN and $0.1 \%$ TFA) and mobile phase $\mathrm{B}(100 \% \mathrm{ACN}$ and $0.1 \%$ TFA). The eluent linearly changed from 80:20 (A: B) to 40:60 (A: B) over 2 min and set back to 80:20 (A: B) in $3.5 \mathrm{~min}$, with a flow rate of $0.250 \mathrm{ml} / \mathrm{min}$. The injection volume was $5 \mu \mathrm{l}$, and UV absorbance was measured at $210 \mathrm{~nm}$. BSA standards $(10-200 \mu \mathrm{g} / \mathrm{ml})$ were used for calibration.

\section{In Vitro Degradation of PLHMGA Microspheres}

The in vitro degradation was studied by transferring $20 \mathrm{mg}$ of the microspheres into eppendorf tubes (10 tubes per microspheres batch) to which $1.5 \mathrm{ml}$ of PBS buffer $\left(\mathrm{pH} 7.4,0.033 \mathrm{M} \mathrm{NaH}{ }_{2} \mathrm{PO}_{4}, 0.066 \mathrm{M} \mathrm{Na}{ }_{2} \mathrm{HPO}_{4}\right.$, $0.056 \mathrm{M} \mathrm{NaCl}$ and $0.05 \%(\mathrm{w} / \mathrm{w}) \mathrm{NaN}_{3}$ ) was added. The samples were incubated at $37^{\circ} \mathrm{C}$ while gently shaken. In order to keep the $\mathrm{pH}$ constant, at regular time points $1 \mathrm{ml}$ of the buffer was replaced by fresh buffer. Samples of the microspheres were removed at different time points, and after washing them twice with $1 \mathrm{ml}$ RO water, they were freeze dried, and the weight of samples was measured. The remaining insoluble residues were characterized using NMR, DSC and GPG. 
Table I Characteristics of the PLBMGA and PLHMGA
${ }^{a}$ Copolymers used to study the effect of $M_{n}$ on BSA release

${ }^{b} \mathrm{M}$ monomer BMMG,

$\mathrm{D}, \mathrm{L}=\mathrm{D}, \mathrm{L}$-lactide

${ }^{c} M / 1=10$

*synthesized by using recrystallized monomer

\begin{tabular}{|c|c|c|c|c|c|}
\hline & Polymer & Feed ratio $M / D, L^{b}$ & $\begin{array}{l}\text { Copolymer } \\
\text { Composition (NMR) }\end{array}$ & $M_{n}(\mathrm{~kg} / \mathrm{mol})$ & $M_{w}(\mathrm{~kg} / \mathrm{mol})$ \\
\hline \multirow[t]{8}{*}{ PLBMGA } & $P_{1}$ & $25 / 75$ & $21 / 79$ & 14 & 22 \\
\hline & $\mathrm{P}_{2}{ }^{*}$ & $25 / 75$ & $22 / 78$ & 16 & 35 \\
\hline & $P_{3}$ & $35 / 65$ & $30 / 70$ & 11 & 16 \\
\hline & $\mathrm{P}_{4} *$ & $35 / 65$ & $35 / 65$ & 21 & 41 \\
\hline & a ${ }^{C} P_{5} *$ & $35 / 65$ & $32 / 68$ & 10 & 16 \\
\hline & $P_{6} *$ & $35 / 65$ & $31 / 69$ & 18 & 42 \\
\hline & $P_{7}$ & $50 / 50$ & $44 / 56$ & 10 & 15 \\
\hline & $\mathrm{P}_{8}{ }^{*}$ & $50 / 50$ & $46 / 54$ & 20 & 51 \\
\hline \multirow[t]{8}{*}{ PLHMGA } & $P_{9}$ & $25 / 75$ & $20 / 80$ & 11 & 19 \\
\hline & $P_{10} *$ & $25 / 75$ & $20 / 80$ & 13 & 30 \\
\hline & $P_{11}$ & $35 / 65$ & $31 / 69$ & 8 & 13 \\
\hline & $P_{12} *$ & $35 / 65$ & $33 / 67$ & 20 & 37 \\
\hline & ${ }_{a}{ }^{C} P_{13} *$ & $35 / 65$ & $33 / 67$ & 10 & 15 \\
\hline & $\left\{P_{14}{ }^{*}\right.$ & $35 / 65$ & $30 / 70$ & 19 & 40 \\
\hline & $P_{15}$ & $50 / 50$ & $47 / 53$ & 4 & 7 \\
\hline & $P_{16} *$ & $50 / 50$ & $46 / 54$ & 19 & 45 \\
\hline
\end{tabular}

\section{Protein Stability}

Fluorescence spectroscopy was used following the procedure described earlier (17) to investigate possible changes in the tertiary structure of the released protein. Excitation was at $295 \mathrm{~nm}$, and fluorescence emission spectra of the released samples (300-450 nm) were measured in $1-\mathrm{cm}$ quartz cuvettes on a Fluorolog ${ }^{\circledR}$-spectrofluorometer (Horriba Jobin Yvon, Edison, NJ, USA), and average of 3 scans was taken.

A GPC system comprised a Waters 2475 Multi $\lambda$ Fluorescence Detector (excitation at 295/emission at 348) and a Superdex 200 10/300 GL column (GE Healtcare, Piscataway, USA) was used to investigate the presence of possible soluble protein aggregates in the released samples. The mobile phase was a phosphate buffer $(\mathrm{pH} 6.8,0.1 \mathrm{M}$ ), the flow rate was $0.5 \mathrm{ml} / \mathrm{min}$ and the injection volume was $50 \mu \mathrm{l}$. The run time was $70 \mathrm{~min}$, and the area under the curve (AUC) was measured to calculate the percentage of monomer, dimer and aggregates in standard $(50 \mu \mathrm{g} / \mathrm{ml})$ and released samples (ca. $50 \mu \mathrm{g} / \mathrm{ml}$ ).

\section{RESULTS AND DISCUSSION}

\section{Synthesis and Characterization of PLHMGA Differing in Copolymer Composition and Molecular Weight}

Random copolymers of benzyl protected hydroxyl methyl glycolide (BHMG) and D, L-lactide with different monomer molar ratios $(25 / 75,35 / 65$ and 50/50) were synthesized in the melt at $130^{\circ} \mathrm{C}$ by ring opening polymerization using $\mathrm{BnOH}$ and $\mathrm{SnOct}_{2}$ as initiator and catalyst, respectively. The obtained copolymers (PLBMGA) were obtained in high yields $(>90 \%)$, and the copolymer composition, as determined by NMR analysis, closely matched that of the feed (Table I). The DSG thermograms showed that PLBMGAs were completely amorphous with a $\mathrm{T}_{\mathrm{g}}$ of 38 ,
Table II Characteristics of BSA-Loaded PLHMGA Microspheres $(n=3)$ Prepared Using PLHMGA Copolymers with Different Copolymer Composition and Molecular Weights

${ }^{a}$ LE loading efficiency, ${ }^{b} L C$ loading capacity

c Microspheres used to study the effect of $M_{n}$ on BSA release

\begin{tabular}{llllll}
\hline Polymer (Table I) & Formulation & $\begin{array}{l}\text { Polymer concentration } \\
\text { in DCM \% }(\mathrm{W} / \mathrm{w})\end{array}$ & $\begin{array}{l}\text { Volume weight } \\
\text { mean }(\mu \mathrm{m})\end{array}$ & $\mathrm{LE}^{a}(\%)$ & $\mathrm{LC}^{b}(\%)$ \\
\hline$P_{9}$ & $\mathrm{~F}_{1}$ & 20 & $10.3 \pm 0.9$ & $84.1 \pm 1.2$ & $3.6 \pm 0.1$ \\
$P_{10}$ & $F_{2}$ & $15.0 \pm 1.7$ & $82.9 \pm 3.2$ & $2.6 \pm 0.1$ \\
$P_{11}$ & $F_{3}$ & $9.6 \pm 1.1$ & $85.0 \pm 1.4$ & $3.6 \pm 0.1$ \\
$P_{12}$ & $F_{4}$ & 25 & $10.8 \pm 3.1$ & $81.6 \pm 3.5$ & $2.7 \pm 0.1$ \\
$P_{13}$ & $\left\{F_{5}\right.$ & 20 & $5.4 \pm 0.3$ & $89.1 \pm 4.8$ & $3.8 \pm 0.1$ \\
$P_{14}$ & $F_{6}$ & 20 & $7.0 \pm 2.4$ & $93.3 \pm 4.8$ & $4.0 \pm 0.2$ \\
$P_{15}$ & $F_{7}$ & 20 & $10.6 \pm 0.5$ & $49.0 \pm 2.8$ & $2.2 \pm 0.2$ \\
$P_{16}$ & $F_{8}$ & 25 & $13.8 \pm 0.5$ & $86.5 \pm 2.2$ & $3.0 \pm 0.1$ \\
\hline
\end{tabular}


37 and $34^{\circ} \mathrm{C}$ for the $25 / 75,35 / 65$ and $50 / 50$ copolymer, respectively, in agreement with our previous findings $(17,18)$. Complete removal of the protecting benzyl group was confirmed by NMR analysis. The deprotected PLHMGA copolymers were obtained in a high yield $(>80 \%)$ with a $\mathrm{T}_{\mathrm{g}}$ of 36,40 and $37^{\circ} \mathrm{C}$ for $25 / 75,35 / 65$ and 50/50 copolymer, respectively.

Table I shows that the molecular weights of the synthesized polymers with different copolymer composition $\left(\mathrm{P}_{9}, \mathrm{P}_{11}\right.$ and $\left.\mathrm{P}_{15}\right)$ were rather low, which might be ascribed to the presence of, e.g., hydroxyl-containing impurities in the monomer that might act as initiator of the ring-opening polymerization. In order to obtain copolymers with higher molecular weight, BMMG was therefore recrystallized from MTBE to reduce the impurities. It was shown that this recrystallized monomer had a higher melting point $\left(\mathrm{T}_{\mathrm{m}}=\right.$ $\left.94^{\circ} \mathrm{C}, \Delta \mathrm{H}=99 \mathrm{~J} / \mathrm{g}\right)$ in comparison to the crystallized monomer $\left(\mathrm{T}_{\mathrm{m}}=83^{\circ} \mathrm{C}, \Delta \mathrm{H}=78 \mathrm{~J} / \mathrm{g}\right)$, demonstrating that the recrystallization resulted in a monomer batch with less impurities. The results showed an increase in $\mathrm{M}_{\mathrm{n}}$ and $\mathrm{M}_{\mathrm{w}}$ for the copolymer 35/65 $\left(M_{n}\right.$ from 8 to $20 \mathrm{~kg} / \mathrm{mol}, M_{w}$ from 13 to $37 \mathrm{~kg} / \mathrm{mol}$, compare $\mathrm{P}_{11}$ and $\mathrm{P}_{12}$ ) and 50/50 $\left(\mathrm{M}_{\mathrm{n}}\right.$ from 4 tol9 $\mathrm{kg} / \mathrm{mol}, \mathrm{M}_{\mathrm{w}}$ from 7 to $45 \mathrm{~kg} / \mathrm{mol}$, compare $\mathrm{P}_{15}$ and $\mathrm{P}_{16}$ ) using the recrystallized monomer, demonstrating that a reduction of the impurities resulted in polymers with higher molecular weights.

PLHMGA with $35 \mathrm{~mol} \%$ BHMG and $65 \mathrm{~mol}^{\%} \mathrm{D}$, Llactide of different molecular weights $\left(\mathrm{M}_{\mathrm{n}}=10\right.$ and $19 \mathrm{~kg} / \mathrm{mol}$ ) were synthesized using recrystallized BMMG with $\mathrm{M} / \mathrm{I}$ ratio of 10 and 100 , respectively (Table $\mathrm{I}, \mathrm{P}_{13}$ and $\left.\mathrm{P}_{14}\right)$.

\section{Preparation and Characterization of Microspheres}

BSA-loaded PLHMGA microspheres were prepared using a double emulsion evaporation method. The characteristics of the microspheres prepared using copolymers with

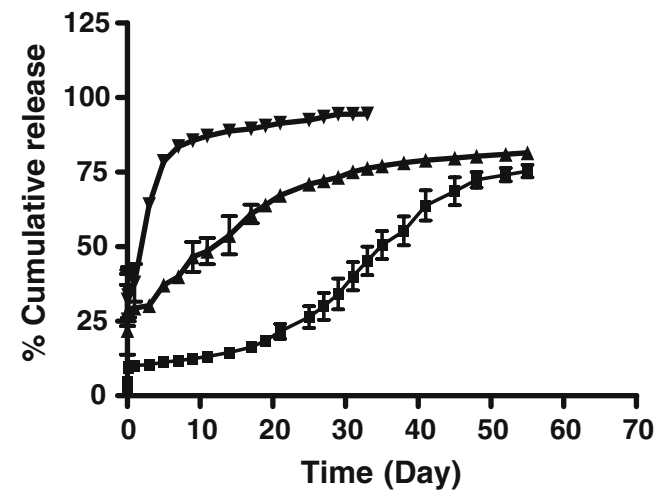

Fig. 2 BSA release from PLHMGA microspheres prepared from copolymers with different copolymer composition (Table II; $F_{1}, F_{3}$ and $F_{7}$ ); ( $\mathbf{\nabla})$ 50/50, ( $\mathbf{\Delta}$ ) 35/65 and (- $)$ 25/75.

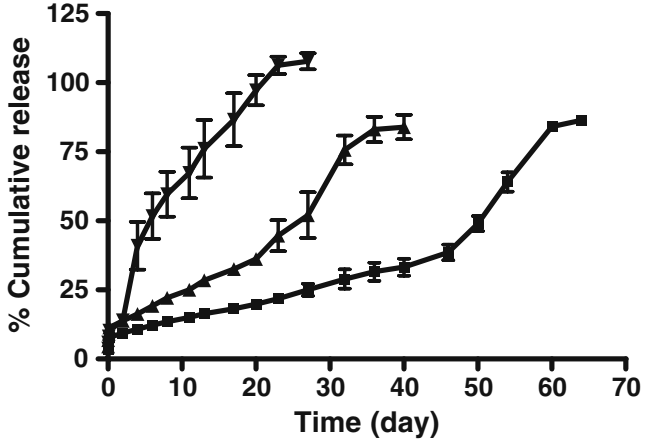

Fig. 3 BSA release from microspheres prepared from copolymers synthesized from recrystallized BMMG (Table II; $F_{2}, F_{4}$ and $F_{8}$ ) with the copolymer concentration of 25\% (W/W); ( $)$ 50/50, ( $25 / 75$.

different copolymer composition (25/75, 35/65 and 50/50) and molecular weights are shown in Table II.

Table II shows that the size of the particles ranged from 5 to $15 \mu \mathrm{m}$. The loading efficiency was high $(>80 \%)$ and independent of the polymer concentration and polymer molecular weight, except for microspheres prepared using the copolymer $50 / 50$ at a low polymer concentration and low $\mathrm{M}_{\mathrm{n}}\left(\mathrm{F}_{7}, \mathrm{LE} \sim 49 \%\right)$. The high LE is probably caused by a fast precipitation of the polymer during evaporation of the solvent, which in turn hampers the drug diffusion into the continuous phase (22). Table II also shows that the particle size and LE were not dependent on the molecular weight of the copolymer used for preparation of the microspheres $\left(\mathrm{F}_{5}\right.$ and $\left.\mathrm{F}_{6}\right)$.

\section{In Vitro Release of BSA from PLHMGA Microspheres; Effect of Copolymer Composition and Molecular Weight}

Fig. 2 shows the BSA release from microspheres of PLHMGA with different copolymer composition.

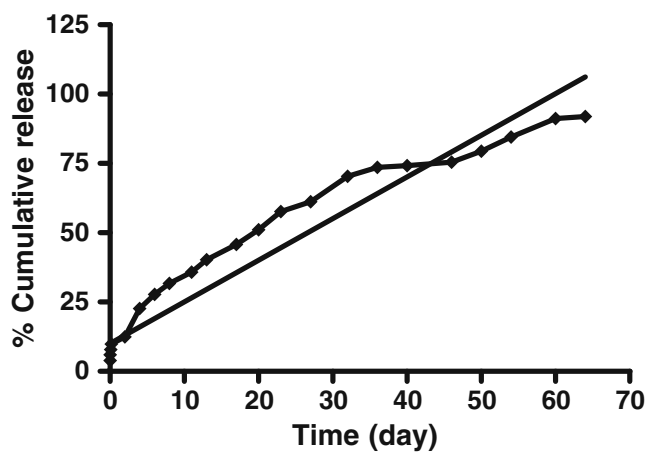

Fig. 4 Calculated release profile of BSA from a cocktail of microspheres $\left(F_{2}, F_{4}, F_{8}\right.$, ratio $\left.I / I / I\right)$. The straight line gives the zero-order release profile after a burst of $10 \%$. 


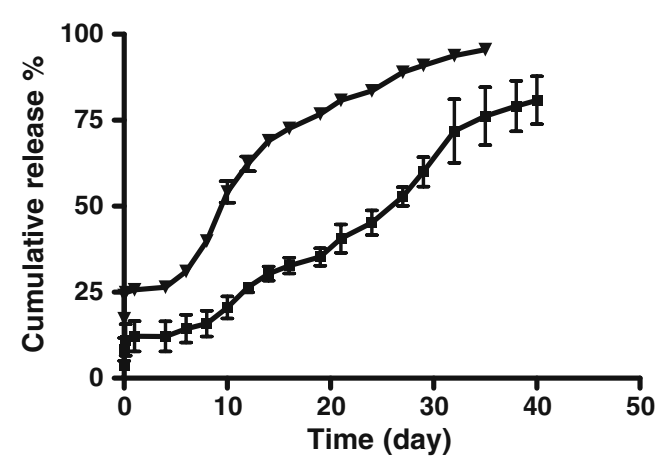

Fig. 5 BSA release from PLHMGA microspheres prepared from 35/65 copolymers (Table II; $F_{5}$ and $F_{6}$ ) with different $M_{n} ;(\boldsymbol{\nabla}) 10 \mathrm{~kg} / \mathrm{mol}$ $\left(\mathrm{P}_{13}\right.$, Table I) and $(\mathbf{\square}) 19 \mathrm{~kg} / \mathrm{mol}\left(\mathrm{P}_{14}\right.$, Table I).

Microspheres made from PLHMGA 50/50 showed a burst release of BSA ( $\sim 40 \%$ of the loaded amount), and thereafter more than $90 \%$ of the protein was released within 2 weeks. The burst release from PLHMGA microspheres decreased to $30 \%$ when the molar ratio of the hydrophilic monomer decreased to $35 \%$. After the burst, for these microspheres, a sustained release for 30 days was observed. PLHMGA 25/75 microspheres showed a low burst $(<10 \%)$, and after a non-phase release ( $\sim 20$ days), as polymer degradation progressed, BSA was released for the next 35 days. However, the release from microspheres of copolymer $35 / 65$ and $25 / 75$ reached $\sim 80 \%$ of the loaded amount. Likely, the possible deleterious conditions for the protein during degradation of the microspheres might have led to denaturation and/or aggregation of BSA. Excipients can be used to counteract these adverse effects $(23,24)$.

BSA-loaded microspheres were also prepared from copolymers with higher molecular weight (Table I; $\mathrm{P}_{10}$, $\mathrm{P}_{12}$ and $\mathrm{P}_{16}$ ), and the copolymer concentration of the DCM solution used to prepare the microspheres was increased from $20 \%(\mathrm{w} / \mathrm{w})$ to $25 \%(\mathrm{w} / \mathrm{w})$. The BSA release profiles from the prepared microspheres are shown in Fig. 3.

This figure shows that the microspheres prepared with higher copolymer concentration and molecular weight showed a substantially lower burst release $(\sim 10 \%)$ than those of Fig. $2(10-40 \%)$. A possible explanation for this decrease in burst release is that an increasing polymer concentration and molecular weight resulted in a decrease of the porosity of the microspheres $(25,26)$. Indeed, microspheres of formulation $\mathrm{F}_{7}$ were highly porous, whereas those of $\mathrm{F}_{8}$ were non-porous (SEM analysis). A quantitative release of BSA from microspheres of 50/50 copolymer in 20 days was observed. BSA was released in a sustained manner for 35 days from microspheres of copolymer 35/65 (acceleration of release around day 25, due to degradation of the particles; see Fig. 6 and its discussion in the text), while microspheres based on copolymer 25/75 showed a slow release for 40 days. Thereafter, a faster release was observed between day 50 and 70, which is caused by degradation of the microspheres.

The degradation controlled release of BSA from PLHMGA microspheres opens the possibility to have release for a prolonged time (not feasible with only one type of microspheres) using cocktails of microspheres. As an example, the calculated release of BSA from a $1 / 1 / 1$ mixture of 50/50, 35/65 and 25/75 is shown in Fig. 4. This figure shows that after a small burst, the protein is released with almost zero order kinetics for 65 days..

Fig. 5 shows the release of BSA from PLHMGA microspheres prepared with copolymers with different molecular weight.

The microspheres prepared from copolymers with a rather low $\mathrm{M}_{\mathrm{n}}(10 \mathrm{~kg} / \mathrm{mol})$ showed a burst around $30 \%$ followed by a sustained release for 30 days. Moreover, a quantitative release of BSA was observed in 35 days. Increasing the $\mathrm{M}_{\mathrm{n}}$ to $19 \mathrm{~kg} / \mathrm{mol}$ decreased the burst to $10 \%$, and thereafter a sustained release of BSA up to $80 \%$ was observed for 40 days. The decrease in burst release with increasing molecular weight of the copolymer used for the preparation of the microspheres has also been reported by other researchers $(25,27)$ and is most likely caused by the decrease in porosity of the microspheres. However, differences in porosity using SEM could not be seen; likely, the pores are smaller than detectable by SEM. The results also
Fig. 6 (a) Relative mass decrease of the PLHMGA microspheres and (b) number average molecular weight $\left(M_{n}\right)$ of PLHMGA as a function of time; the copolymer composition was 50/50 ( $\boldsymbol{\nabla})$,

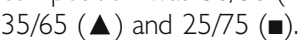
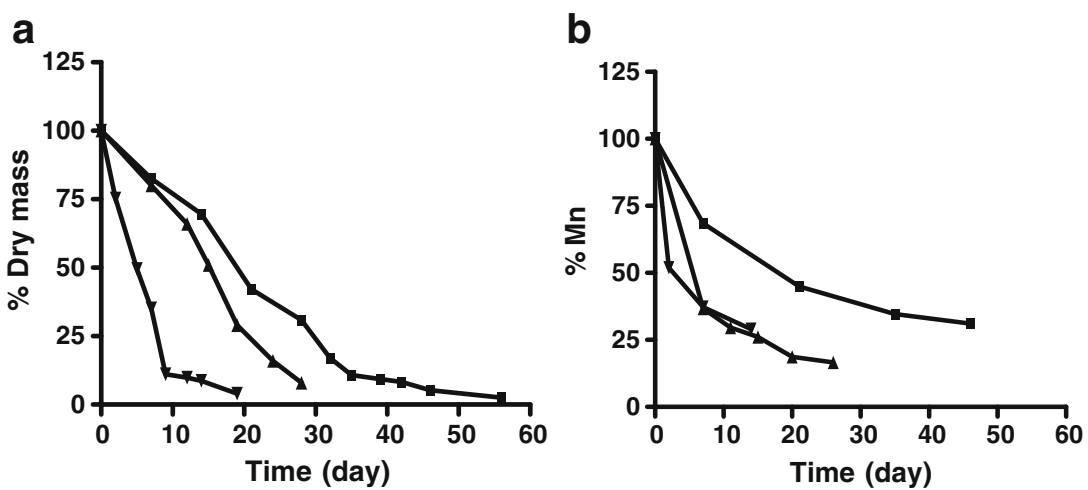
showed that there is hardly any effect of the polymer molecular weight on the duration of the release.

\section{In Vitro Degradation of PLHMGA Microspheres}

It is generally accepted that the degradation of PLGA and related polymers proceeds via chemical hydrolysis of the ester bond $(3,28,29)$; enzyme catalysis hardly contributes to the degradation of implants (30) and microspheres (31). It can therefore be expected that the degradation of PLHMGA microspheres is mainly controlled by hydrolytic degradation, given the resemblance in structure between this polymer and PLGA.

Microspheres of PLHMGA with different copolymer composition incubated in a phosphate buffer $(155 \mathrm{mM}, \mathrm{pH}$ 7.4) at $37^{\circ} \mathrm{C}$ showed a continuous weight loss in time (Fig. 6a). Microspheres of 50/50 copolymer completely degraded in less than 20 days, in agreement with Leemhuis
Fig. 7 Scanning electron micrographs of the PLHMGA microspheres during in vitro degradation.

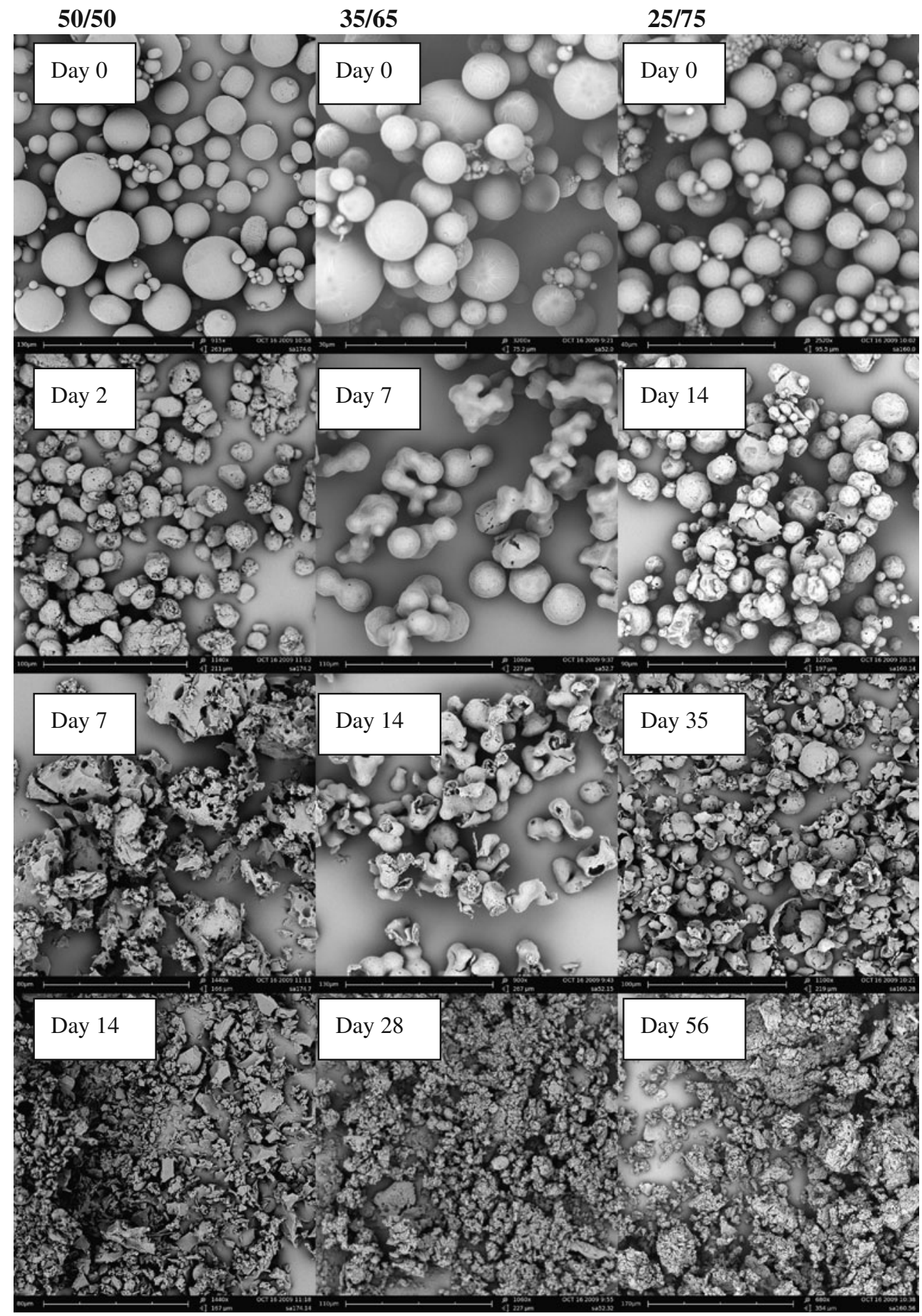


et al. (32). Decreasing the BMMG ratio to $35 \%$ and $25 \%$ prolonged the complete degradation process to 30 and 55 days, respectively, again in line with previous findings (32). Fig. $6 \mathrm{~b}$ shows that the $\mathrm{M}_{\mathrm{n}}$ of the non-dissolved polymer decreased in time, which indicates that microspheres degrade via bulk erosion $(17,32)$.

In contrast to our previous study (17), where insoluble residues composed of crystalline oligomers of lactic acid remained, the PLHMGA microspheres degraded completely. Because in the present study D,L- lactide instead of L-lactide was used to synthesize the copolymers, upon degradation amorphous D,L-lactic acid fragments are formed (DSC analysis), which in contrast to their crystalline counterparts are susceptible to further hydrolytic degradation $(28,33)$.

Scanning electron micrographs of the PLHMGA microspheres revealed changes in microspheres' morphology during degradation. Fig. 7 shows that the microspheres of the rapidly degrading 50/50 copolymer lost their spherical shape and became porous after 2 days of degradation; after 7 days, mainly particle aggregates remained. SEM analysis at day 14 showed the presence of particle residues, whereas no residues were found at day 20. SEM pictures of microspheres composed of the $35 / 65$ copolymer were partly fused at day 7 , but they remained essentially nonporous. As the degradation proceeded, they lost their spherical shape and were porous at day 14. The particles were fully degraded at day 30 . The microspheres based on the $25 / 75$ copolymer slowly degraded. At day 14 , the particles showed some porosity, and they were completely degraded at day 60.

The degradation of the PLHMGA microspheres prepared from copolymers with different $\mathrm{M}_{\mathrm{n}}$ was studied. The microspheres showed a continuous weight loss in time (Fig. 8a), and they were completely degraded in 30 days. The mass loss was accompanied by a gradual decrease in molecular weight (Fig. 8b). The initial molecular weight of the copolymer had no effect on either the kinetics of mass decrease or on molecular weight decrease. It can be expected that particles prepared of a higher molecular weight polymer degraded slower, because more ester bonds have to be hydrolyzed before soluble products are formed. Obviously, the molecular weight of our copolymers differs not sufficiently to result in clearly different degradation kinetics.

Combining the release (Figs. 2, 3 and 5) and the in vitro degradation data (Figs. 6 and 8), it can be concluded that the release of BSA is to a large extent governed by the degradation of the microparticles. Obviously, once the protein molecules present in the pores of the particles are released (burst release), protein entrapped in the microsphere matrix has a very low mobility and is only released in the environment once the matrix has undergone substantial degradation.

\section{Protein Stability}

The fluorescence emission spectrum of released BSA showed no difference in intensity and almost completely overlapped with that of native BSA. This means that no changes in the tertiary structure of the protein had occurred. Size exclusion chromatography analysis showed that the monomer/dimer ratio in released samples was the same as in freshly dissolved BSA. Further, extra peaks, e.g., with retention times shorter than BSA dimer (corresponding to soluble aggregates), were not observed. This means that, although some insoluble BSA aggregates were likely formed during release from the slowly degrading microspheres (Figs. 3 and 5), the structural integrity of the released/soluble protein was fully preserved.

\section{CONCLUSIONS}

Microspheres prepared from PLHMGA showed, depending on the copolymer composition, a sustained release of BSA for 15 to 60 days. The microspheres are fully degradable, and the degradation kinetics can be tailored by the copolymer composition. Increasing the BMMG
Fig. 8 (a) Relative weight decrease of PLHMGA microspheres prepared from copolymers with different molecular weights and (b) number average molecular weight decrease $\left(M_{n}\right)$ of PLHMGA as a function of time; the $M_{n}$ of the copolymers was 10 (घ) and $19(\boldsymbol{\nabla}) \mathrm{kg} / \mathrm{mol}$.

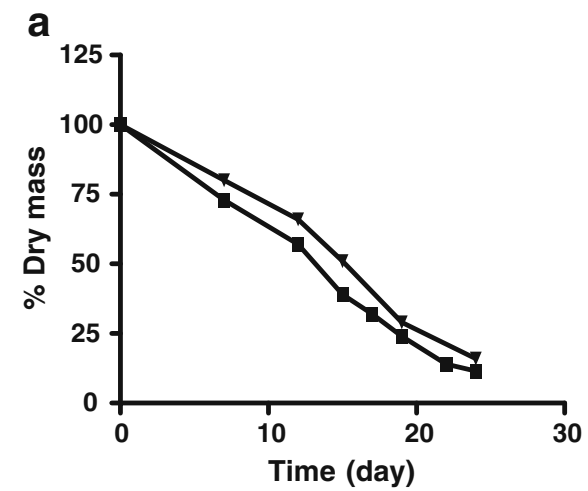

b

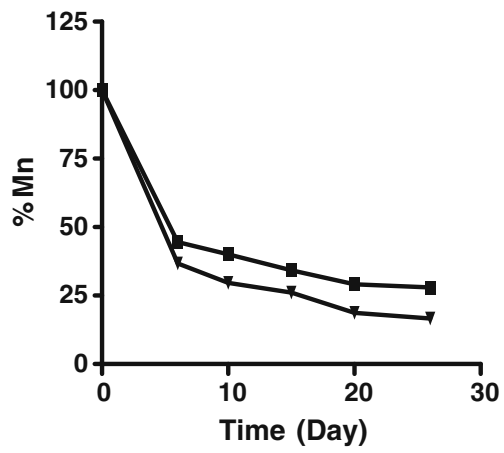


content of the copolymer caused a faster degradation of the copolymer, which in turn resulted in a faster release of the encapsulated BSA. A quantitative release of BSA was observed from fast degrading microspheres (50/50 copolymer). However, $80 \%$ of BSA was recovered from microspheres composed of copolymer 35/65 and 25/75, which is possibly due to the formation of insoluble protein aggregates. Fluorescence spectroscopy and size exclusion chromatography showed that the released soluble BSA retained its structural integrity. These findings show that microspheres of PLHMGA are promising systems for the delivery of pharmaceutical proteins. In our future studies, we are focusing on suitable excipients for the stabilization of encapsulated proteins in order to achieve a complete release of proteins, particularly from the slowly degrading microspheres.

Open Access This article is distributed under the terms of the Creative Commons Attribution Noncommercial License which permits any noncommercial use, distribution, and reproduction in any medium, provided the original author(s) and source are credited.

\section{REFERENCES}

1. Gupta PK, Mehta RC, Douglas RH, Luca PP. In vivo evaluation of biodegradable progesterone microspheres in mares. Pharm Res. 1992;9:1502-6.

2. Mehta RC, Jeyanthi R, Calls S, Thanoo BC, Burton KW, DeLuca PP. Biodegradable microspheres as depot system for patenteral delivery of peptide drugs. J Control Rel. 1994;29:375-84.

3. Anderson JM, Shive MS. Biodegradation and biocompatibility of PLA and PLGA microspheres. Adv Drug Deliv Rev. 1997;28:5-24.

4. Kang J, Schwendeman SP. Comparison of the effects of $\mathrm{Mg}(\mathrm{OH})_{2}$ and sucrose on the stability of bovine serum albumin encapsulated in injectable poly(lactide-co-glycolide) implants. Biomaterials. 2002;23:239-45.

5. Tia E, Jichao K, Steven PS, John FC. BSA degradation under acidic conditions: a model for protein instability during release from PLGA delivery systems. J Pharm Sci-US. 2006;95:1626-39.

6. Fu K, Pack DW, Klibanov AM, Langer R. Visual evidence of acidic environment within degrading Poly(lactic-co-glycolic acid) (PLGA) microspheres. Pharm Res. 2000;17:100-6.

7. Wong-Moon KC, Sun X, Nguyen XC, Quan BP, Shen K, Burke PA. NMR spectroscopic evaluation of the internal environment of PLGA microspheres. Mol Pharm. 2008;5:654-64.

8. van de Weert M, Hennink WE, Jiskoot W. Protein instability in poly (lactic-co-glycolic acid) microparticles. Pharm Res. 2000;17:1159-67.

9. Crotts G, Sah H, Park TG. Adsorption determines in-vitro protein release rate from biodegradable microspheres: quantitative analysis of surface area during degradation. J Control Release. 1997;47:101-11.

10. Calis S, Jeyanthi R, Tsai T, Mehta RC, DeLuca PP. Adsorption of salmon calcitonin to PLGA microspheres. Pharm Res. 1995; 12:1072-6.
11. Crotts G, Park TG. Stability and release of bovine serum albumin encapsulated within poly(lactide-co-glycolide) microparticles. J Control Release. 1997;44:123-34.

12. Zhang Y, Sophocleous A, Schwendeman S. Inhibition of peptide acylation in PLGA microspheres with water-soluble divalent cationic salts. Pharm Res. 2009;26:1986-94.

13. Houchin ML, Topp EM. Chemical degradation of peptides and proteins in PLGA: A review of reactions and mechanisms. J Pharm Sci-US. 2008;97:2395-404.

14. Bucciantini M, Giannoni E, Chiti F, Baroni F, Formigli L, Zurdo $\mathrm{J}$, et al. Inherent toxicity of aggregates implies a common mechanism for protein misfolding diseases. Nature. 2002; 416:507-11.

15. Stefani M, Dobson C. Protein aggregation and aggregate toxicity: new insights into protein folding, misfolding diseases and biological evolution. J Mol Med-JMM. 2003;81:678-99.

16. Hermeling S, Crommelin D, Schellekens H, Jiskoot W. Structureimmunogenicity relationships of therapeutic proteins. Pharm Res. 2004;21:897-903.

17. Ghassemi AH, van Steenbergen MJ, Talsma H, van Nostrum CF, Jiskoot W, Crommelin DJA, et al. Preparation and characterization of protein loaded microspheres based on a hydroxylated aliphatic polyester, poly(lactic-co-hydroxymethyl glycolic acid). J Control Release. 2009;138:57-63.

18. Leemhuis M, van Nostrum CF, Kruijtzer JAW, Zhong ZY, ten Breteler MR, Dijkstra PJ, et al. Functionalized poly(alpha-hydroxy acid)s via ring-opening polymerization: toward hydrophilic polyesters with pendant hydroxyl groups. Macromolecules. 2006;39:3500-8.

19. Wang J, Wang BM, Schwendeman SP. Characterization of the initial burst release of a model peptide from poly $(\mathrm{D}, \mathrm{L}$-lactide-coglycolide) microspheres. J Control Release. 2002;82:289-307.

20. Ye M, Kim S, Park K. Issues in long-term protein delivery using biodegradable microparticles. J Control Release, doi: 10.1016/j. jconrel.2010.05.011(2010).

21. Hongkee S. A new strategy to determine the actual protein content of poly (lactide-co-glycolide) microspheres. J Pharm Sci-US. 1997;86:1315-8.

22. Rafati H, Coombes AGA, Adler J, Holland J, Davis SS. Proteinloaded poly(DL-lactide-co-glycolide) microparticles for oral administration: formulation, structural and release characteristics. J Control Release. 1997;43:89-102.

23. Giteau A, Venier-Julienne MC, Aubert-Pouëssel A, Benoit JP. How to achieve sustained and complete protein release from PLGA-based microparticles? Int J Pharm. 2008;350:14-26.

24. Sophocleous AM, Zhang Y, Schwendeman SP. A new class of inhibitors of peptide sorption and acylation in PLGA. J Control Release. 2009;137:179-84.

25. Yang Y-Y, Chung T-S, Ping Ng N. Morphology, drug distribution, and in-vitro release profiles of biodegradable polymeric microspheres containing protein fabricated by double-emulsion solvent extraction/evaporation method. Biomaterials. 2001;22: 231-41.

26. Sah H, Toddywala R, Chien YW. The influence of biodegradable microcapsule formulations on the controlled release of a protein. J Control Release. 1994;30:201-11.

27. Kissel T, Li YX, Volland C, Görich S, Koneberg R. Parenteral protein delivery systems using biodegradable polyesters of ABA block structure, containing hydrophobic poly(lactide-co-glycolide) A blocks and hydrophilic poly(ethylene oxide) B blocks. J Control Release. 1996;39:315-26.

28. Vert M, Li S, Garreau H. More about the degradation of LA/GA-derived matrices in aqueous media. J Control Release. 1991;16:15-26.

29. Vert M, Mauduit J, Li S. Biodegradation of PLA/GA polymers: increasing complexity. Biomaterials. 1994;15:1209-13. 
30. Schakenraad JM, Hardonk MJ, Feijen J, Molenaar I, Nieuwenhuis P. Enzymatic activity toward poly(L-lactic acid) implants. J Biomed Mater Res. 1990;24:529-45.

31. Visscher GE, Robison RL, Maulding HV, Fong JW, Pearson JE, Argentieri GJ. Biodegradation of and tissue reaction to 50:50 poly (DL-lactide-co-glycolide) microcapsules. J Biomed Mater Res. 1985;19:349-65.
32. Leemhuis M, Kruijtzer JAW, van Nostrum CF, Hennink WE. In vitro hydrolytic degradation of hydroxyl-functionalized poly(alphahydroxy acid)s. Biomacromolecules. 2007;8:2943-9.

33. Li SM, Garreau H, Vert M. Structure-property relationships in the case of the degradation of massive aliphatic poly $(\alpha$-hydroxy acids) in aqueous media. J Mater Sci-Mater Med. 1990;1:12330. 